\title{
STABILIZATION OF UNSTABLE PERIODIC ORBIT IN CHAOTIC DUFFING-HOLMES OSCILLATOR BY SECOND ORDER RESONANT NEGATIVE FEEDBACK *
}

\author{
A. Tamaševičius ${ }^{\text {a }}$, E. Tamaševičiūtė ${ }^{\mathrm{a}, \mathrm{b}}, \mathrm{G}$. Mykolaitis ${ }^{\mathrm{a}}$, and S. Bumeliené ${ }^{\mathrm{a}}$

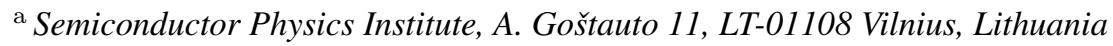 \\ E-mail: tamasev@pfi.lt \\ ${ }^{\mathrm{b}}$ Department of Radiophysics, Vilnius University, Sauletekio 9, LT-10222 Vilnius, Lithuania
}

Received 13 June 2007

\begin{abstract}
We consider a second order linear resonator inserted in the negative feedback loop of the chaotic Duffing-Holmes oscillator for stabilizing unstable periodic orbit. Mathematical model is discussed and numerical simulations are presented. An analogue electronic controller is described. Experiments have been performed with an electronic version of the Duffing-Holmes oscillator. Stabilization of periodic oscillations can be achieved with a small control force.
\end{abstract}

Keywords: nonlinear dynamics, low-dimensional chaos, control of chaos

PACS: 05.45.-a, 05.45.Ac, 05.45.Gg

\section{Introduction}

17 years ago Edward Ott, Celso Grebogi, and James Yorke launched a new and very intriguing activity in nonlinear dynamics, called 'Controlling Chaos' [1], still attractive nowadays. It inspired many other researchers to develop alternative control algorithms [2-4]. One of the most successful techniques is the time-continuous delayed feedback control (DFC) method, also known as Pyragas' method [5-7]. Practical implementation of the DFC method requires a delay line in the feedback circuit. At high frequencies (hundreds of megahertz) the delay line is either simply a coaxial transmission cable or a micro-strip line. However, at lower frequencies the delay unit is rather complicated and inconvenient device. In the present paper we suggest an extremely simple technique for controlling unstable periodic orbits embedded in chaotic systems. The basic idea behind the method is to replace the feedback loop containing a delay line with the second order resonant negative feedback (RNF2) where the resonator is tuned to the main frequency of the unstable orbit. As a result the negative feedback damps all the oscillations except the desired periodic orbit. To be specific we consider the chaotic Duffing-

\footnotetext{
* The report presented at the 37th Lithuanian National Physics Conference, 11-13 June 2007, Vilnius, Lithuania.
}

Holmes oscillator [8-10] and employ a second order LC filter similarly to the very recently described technique of synchronization of one-way coupled simple periodic oscillators [11].

\section{Mathematical model and numerical results}

The Duffing-Holmes two-well oscillator [8-10] is given either by the second order nonlinear equation

$$
\ddot{x}+b \dot{x}-x+x^{3}=a \sin \omega t
$$

or by the set of two first order equations

$$
\begin{aligned}
& \dot{x}=y, \\
& \dot{y}=-b y+x-x^{3}+a \sin \omega t .
\end{aligned}
$$

In Eqs. (1), (2) $b$ is the damping coefficient, $a$ and $\omega$ is the amplitude and frequency of external periodic force, respectively. Characteristic frequency of the nonlinear oscillator, applicable in the vicinity of the unforced $(a=0)$ stable steady states $x_{0}= \pm 1$, i. e. close to the bottoms of the wells, is $\omega_{0}=2^{1 / 2}$.

Let us couple the nonlinear Duffing-Holmes oscillator with a damped second order linear oscillator, de- 


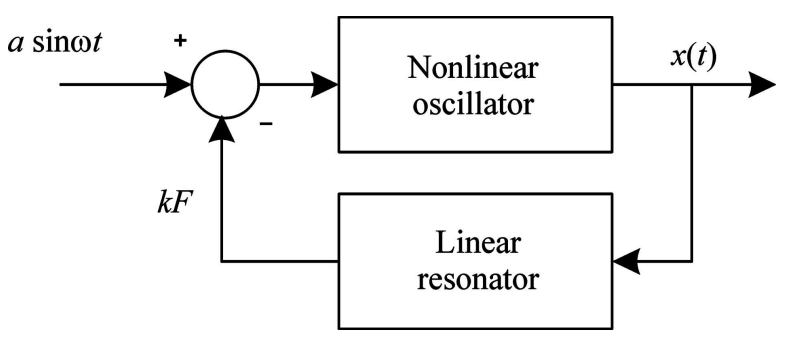

Fig. 1. Block diagram of the control technique.

scribed by dynamical variables $x_{1}, y_{1}$, damping parameter $b_{1}$, and characteristic frequency $\omega_{1}$ :

$$
\begin{aligned}
& \dot{x}=y, \\
& \dot{y}=-b y+x-x^{3}+a \sin \omega t-k\left(y-y_{1}\right), \\
& \dot{x}_{1}=\omega_{1}\left(y_{1}-b_{1} x_{1}\right), \\
& \dot{y}_{1}=\omega_{1}\left[-x_{1}+k_{1}\left(y_{-} y_{1}\right)\right] .
\end{aligned}
$$

Here the coupling coefficients $k$ and $k_{1}$ may be different. Equations (3) can be presented in the following form:

$$
\begin{aligned}
\ddot{x}+b \dot{x}-x+x^{3} & =a \sin \omega t-k F\left(\dot{x}, \dot{x}_{1}, x_{1}\right), \\
\ddot{x}_{1}+\omega_{1} b_{1} \dot{x}_{1}+\omega_{1}^{2} x_{1} & =\omega_{1}^{2} k_{1} F\left(\dot{x}, \dot{x}_{1}, x_{1}\right)
\end{aligned}
$$
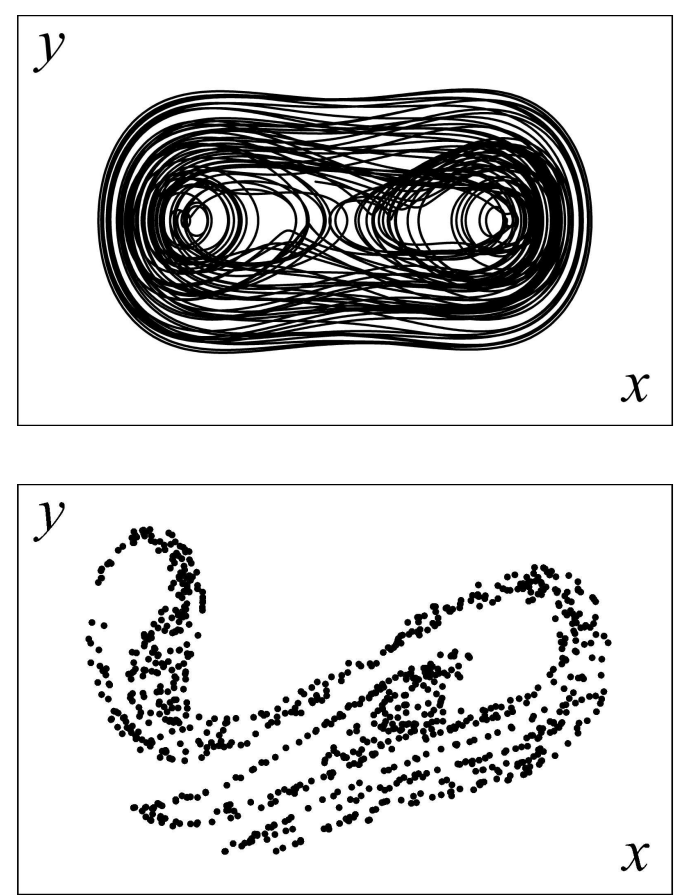

(a)

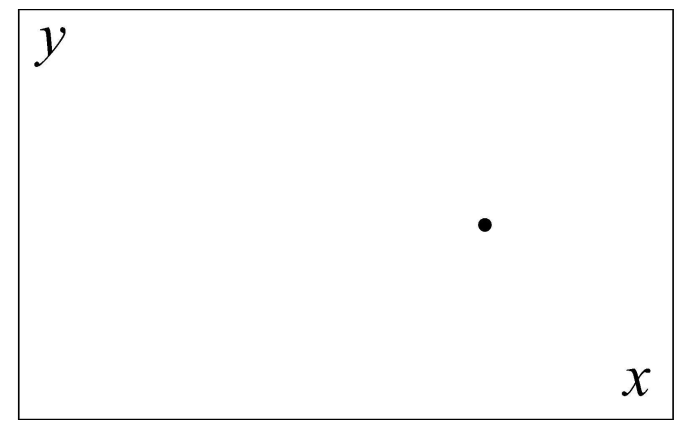

(b)

Fig. 2. Simulated results from Eq. (3). (a) Phase portraits, (b) Poincaré sections: (left) without control, $k=k_{1}=0$, (right) under control, $k=2, k_{1}=1$. Other parameter values: $a=0.45, b=0.1, b_{1}=0.01, \omega=1.3, \omega_{1}=\omega$.
Fig. 3. Waveforms from Eq. (3). Parameters are the same as in Fig. 2. Control is activated at the time moment $t=300$. The lower trace is intentionally shifted down by value -3 .

where the control feedback term $F$ is given by

$$
F\left(\dot{x}, \dot{x}_{1}, x_{1}\right)=\dot{x}-\frac{1}{\omega_{1}} \dot{x}_{1}-b_{1} x_{1} .
$$

Control set-up containing linear resonator in the negative feedback loop of the nonlinear oscillator is sketched in Fig. 1. Numerical results obtained from Eq. (3) using the simulation program Mathematica are shown in Figs. 2 and 3.

\section{Experimental set-up}

The suggested control technique has been tested experimentally using the set-up depicted in Fig. 4. The subcircuit composed of the operational amplifier OA1,

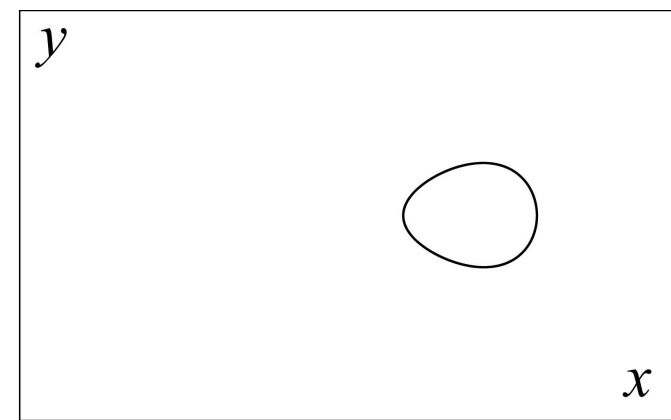

$x$ 


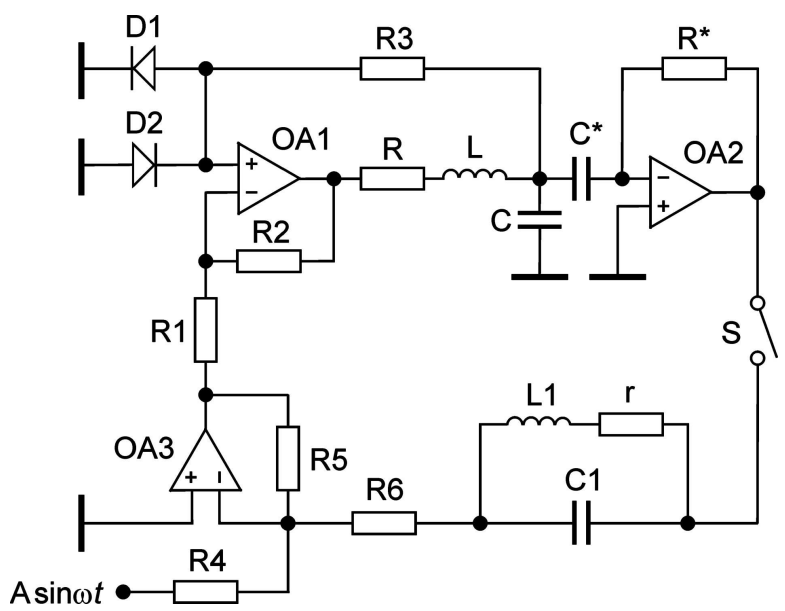

Fig. 4. Circuit diagram of the Duffing-Holmes oscillator with a controller in the feedback loop. $\omega=2 \pi f, L=19 \mathrm{mH}, C=470 \mathrm{nF}$ $\left(f_{0} \approx 1.7 \mathrm{kHz}\right), L_{1}=47 \mathrm{mH}, C_{1}=240 \mathrm{nF}\left(f_{1} \approx 1.5 \mathrm{kHz}\right), R=$ $20 \Omega, r=51 \Omega, R_{1}=R_{2}=R_{3}=10 \mathrm{k} \Omega, R_{4}=R_{5}=1 \mathrm{k} \Omega, R_{6}=$ $510 \Omega$. Here $S$ is an electronic switch.

the $\mathrm{R}-\mathrm{L}-\mathrm{C}$ resonator, the resistors $\mathrm{R} 1-\mathrm{R} 3$ and the diodes D1, D2 is an electronic implementation of the nonautonomous Duffing-Holmes oscillator described in detail elsewhere [12]. It is used in [13] and is similar in a sense to the Young-Silva circuit [14], but is essentially simpler. The rest of the circuit is the controller. The basic element is the resonant filter $\mathrm{r}-\mathrm{L} 1-\mathrm{C} 1$. The $\mathrm{OA} 2$ based stage is a differentiator and the OA3 stage is an adder. The input signal of the differentiator is the voltage across the capacitor $\mathrm{C}, V_{\text {in }}=V_{C}$, the output signal $V_{\text {out }}=-R^{*} \cdot C^{*} \cdot \dot{V}_{C} \propto-\dot{x}=-y$. The val-
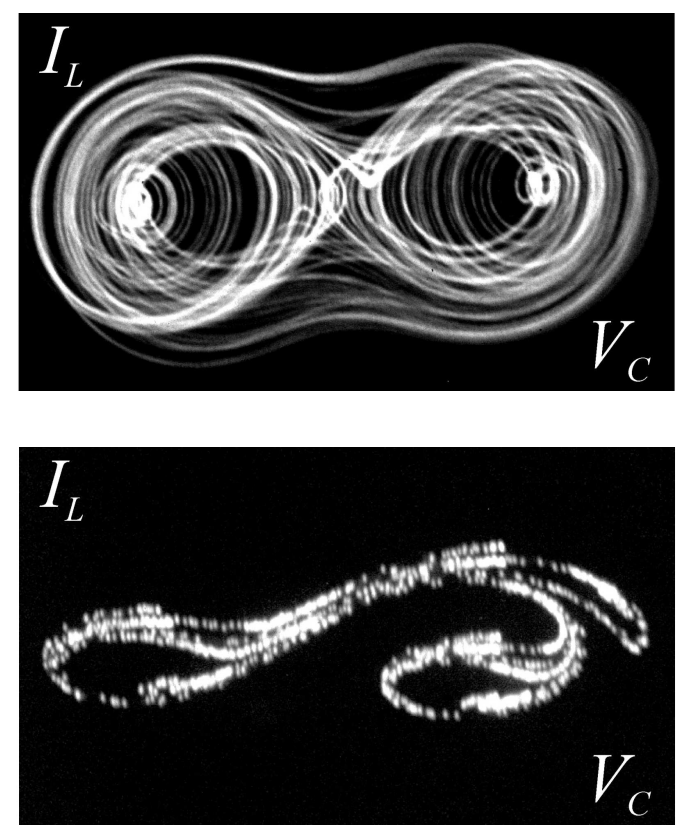

(a)

(b)

Fig. 5. Experimental plots. (a) Phase portraits, (b) Poincaré sections: (left) without control, (right) under control. $A=200 \mathrm{mV}, f=1.5 \mathrm{kHz}$, $f_{1}=f=1.5 \mathrm{kHz}$.

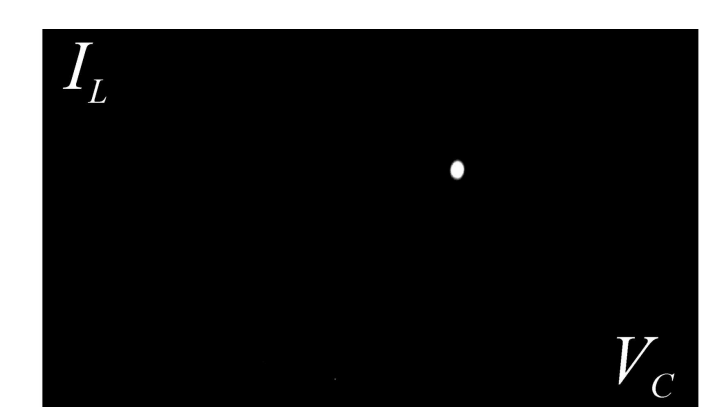

ues of $R^{*}$ and $C^{*}$ are set so that $R^{*} C^{*}=(L C)^{1 / 2}$. The control coefficients $k$ and $k_{1}$ are related to the circuit element values as follows: $k=R_{5} / R_{6}, k_{1}=$ $\left(L_{1} / C_{1}\right)^{1 / 2} / R_{6}$.

\section{Experimental results}

The photos demonstrating a settled behaviour of the free-running oscillator (switch $\mathrm{S}$ is in the opened poshown in Fig. 5. Closed loop and a single dot in the right-hand plots of the phase portraits and the Poincaré sections, respectively, confirm that the RNF2 method successfully stabilizes period-1 orbit. A snapshot of the waveform including transient process is presented in Fig. 6. The experimental results are in a good agreement with the simulated plots in Figs. 2, 3.

\section{Concluding remarks}

Stabilization of the periodic orbit in the DuffingHolmes oscillator has been already demonstrated in earlier papers both numerically [5] and experimentally [15] using the DFC method. As mentioned in the Introduction the RNF2 method has been recently successfully applied to extend the region of synchronization of two simple periodic oscillators [11]. In the present paper we have described a similar RNF2 analogue controller and have applied it to stabilize unstable

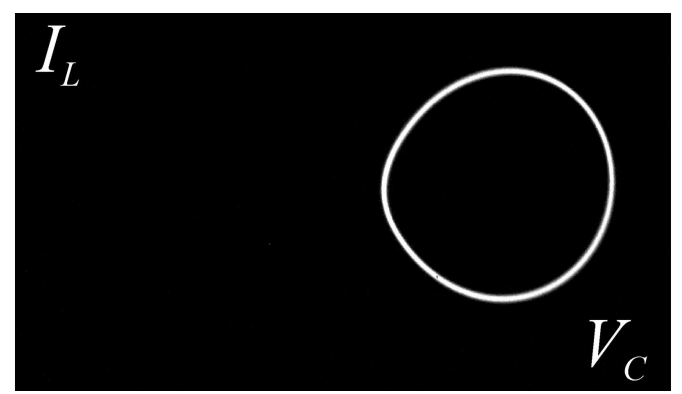
sition) and the controlled oscillator ( $\mathrm{S}$ is closed) are 


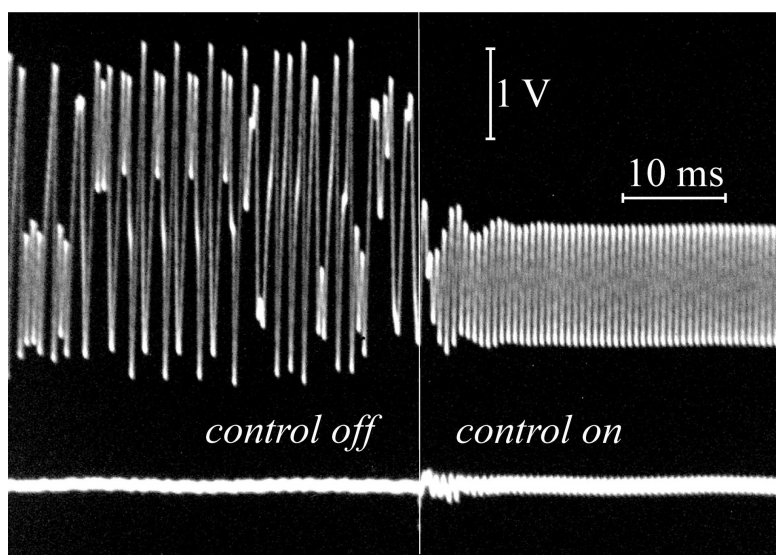

Fig. 6. Experimental waveforms. Upper trace is the output signal $V_{C}(t)$ and lower trace is the control signal $k F(t)$, taken across resistor R6. Parameters are the same as in Fig. 5. Fine vertical line in the photo divides the regions where control is off ( $\mathrm{S}$ opened) and control is on ( $\mathrm{S}$ closed).

periodic orbit in a chaotic electronic circuit that mimics the Duffing-Holmes oscillator [12]. In contrast to the DFC method the residual control signal in the RNF2 method does not vanish. However, it appears to be sufficiently small (about 10\% compared to the main signal). In the RNF2 method only the first harmonic of the stabilized periodic orbit remains unchanged, but its higher harmonics may be slightly affected. Detailed numerical and experimental analysis (not discussed in the previous sections) shows that the main component of the residual control force is just the second harmonic. Therefore the RNF2 controller can be easily improved by inserting in the feedback loop an additional second order resonator with the resonance frequency twice higher as that of the main resonator.

We would like to make some remarks concerning control of chaos via so-called dynamical vibration absorber (DVA) $[2,16]$. The DVA method is similar in a sense to the RNF2 method. A linear "physically small" [2] oscillator (a resonant absorber) is coupled to the main chaotic oscillator. It can change the overall dynamics, thus suppressing chaos and stabilizing periodic orbits. The DVA method has been tested numerically $[2,16]$ by applying it to the Duffing-Ueda oscillator [17], which is similar to the Duffing- Holmes oscillator, but without the term ' $-x$ ' in Eq. (1) and therefore has a simpler single-well potential. The control force in the DVA method is different from that of the RNF2 method. It exploits the difference of coordinates $F \propto\left(x-x_{1}\right)$, instead of the difference of their derivatives, e.g. $F$ given by Eq. (5). Finally, Kapitaniak $[2,16]$ misleadingly attributes the DVA method to chaos control methods "without feedback".

\section{Acknowledgements}

A. T. thanks Kęstutis Pyragas for discussion of the related DVA method. E. T. is grateful to Mantas Meškauskas for help with the Mathematica simulation package.

\section{References}

[1] E. Ott, C. Grebogi, and J. Yorke, Controlling chaos, Phys. Rev. Lett. 64(11), 1196-1199 (1990).

[2] T. Kapitaniak, Controlling Chaos - Theoretical and Practical Methods in Non-Linear Dynamics (Academic Press, London, 1996).

[3] Handbook of Chaos Control, ed. H.G. Shuster (WileyVCH, Weinheim, New York, 1999).

[4] Exploiting Chaotic Properties of Dynamical Systems for their Control: Suppressing, Enhancing, Using Chaos (Theme Issue), eds. S. Lenci and G. Rega, Philos. Trans. R. Soc. London, Ser. A 364(1846), 22672563 (2006).

[5] K. Pyragas, Continuous control of chaos by selfcontrolling feedback, Phys. Lett. A 170(6), 421-428 (1992).

[6] K. Pyragas and A. Tamaševičius, Experimental control of chaos by delayed self-controlling feedback, Phys. Lett. A 180(1,2), 99-102 (1993).

[7] K. Pyragas, Delayed feedback control of chaos, Philos. Trans. R. Soc. London, Ser. A 364(1846), 2309-2334 (2006).

[8] P. Holmes, Nonlinear oscillator with a strange attractor, Philos. Trans. R. Soc. London, Ser. A 292(1394), 419448 (1979).

[9] E. Ott, Chaos in Dynamical Systems (Cambridge University Press, Cambridge, 1993).

[10] K.T. Alligood, T.D. Sauer, and J.A. Yorke, Chaos an Introduction to Dynamical Systems (Springer, New York, Berlin, 2000).

[11] T. Pyragienè, A. Tamaševičius, G. Mykolaitis, and K. Pyragas, Non-invasive control of synchronization region of a forced self-oscillator via a second order filter, Phys. Lett. A 361(4-5), 323-331 (2007).

[12] E. Tamaševičiūtè, A. Tamaševičius, G. Mykolaitis, S. Bumeliene, and E. Lindberg, Nonlinear oscillator for students (to be published elsewhere).

[13] A. Tamaševičius, G. Mykolaitis, V. Pyragas, and K. Pyragas, Delayed feedback control of periodic orbits without torsion in nonautonomous chaotic systems: Theory and experiment, Phys. Rev. E 76(2), 026203-1-6 (2007).

[14] Y.-Ch. Lai, A. Kandangath, S. Krishnamoorthy, J.A. Gaudet, and P.S. de Moura, Inducing chaos by resonant perturbations: Theory and experiment, Phys. Rev. Lett. 94(21), 214101-1-4 (2005). 
[15] T. Hikihara and T. Kawagoshi, An experimental study on stabilization of unstable periodic motion in magneto-elastic chaos, Phys. Lett. A 211(1), 29-36 (1996).

[16] T. Kapitaniak, Controlling chaotic oscillators without feedback, Chaos, Solitons \& Fractals 2(5), 519-530 (1992).

[17] Y. Ueda, Randomly transitional phenomena in the system governed by Duffing's equation, J. Stat. Phys. 20(2), 181-196 (1979).

\title{
NESTABILIOS PERIODINĖS ORBITOS STABILIZAVIMAS CHAOTINIAME DUFFING'O IR HOLMES'O OSCILIATORIUJE ANTROS EILĖS REZONANSINIU NEIGIAMU GRIŽTAMUOJU RYŠIU
}

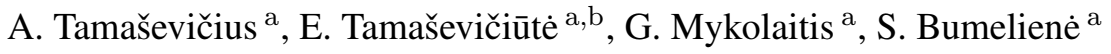 \\ ${ }^{a}$ Puslaidininkiu fizikos institutas, Vilnius, Lietuva \\ ${ }^{\mathrm{b}}$ Vilniaus universitetas, Vilnius, Lietuva
}

\section{Santrauka}

Aprašème labai paprastą nestabiliu periodinių orbitų, esančių chaotiniuose atraktoriuose, stabilizavimo būdą, paremtą antros eilès rezonansiniu neigiamu grižtamuoju ryšiu (RNGR2). Skirtingai nuo Pyrago uždelstojo grižtamojo ryšio (UGR) metodo, RNGR2 metode panaudojama ne vèlinimo linija, bet antros eilès rezonatorius. Toks metodas jau anksčiau buvo pritaikytas periodiniu virpesių generatoriu sinchronizacijos riboms išplèsti. Panašiai kaip ir UGR metode, naudojant RNGR2 metodą nereikia žinoti valdomosios sistemos modelio, tačiau eksperimentiškai realizuoti RNGR2 valdikli yra žymiai lengviau nei UGR valdiklį.

Šiame darbe išnagrinèjome išorinès periodinès jègos veikiamą netiesini Duffing'o ir Holmes'o osciliatorių, kuris plačiame parametru ruože elgiasi chaotiškai. Pateikème diferencialinių lygčių skaitinius sprendinius. Metodą išbandeme ir eksperimentiškai. Šiam tikslui sukūrème analoginį RNGR2 valdiklį. Jo pagrindinis elementas yra antros eilès LC virpesių kontūras, kurio rezonansinis dažnis atitinka išorinès periodinès jègos dažni. RNGR2 valdikli pritaikème elektroninio Duffing'o ir Holmes'o osciliatoriaus valdymui. Prijungus valdiklį, po neilgo pereinamojo proceso osciliatorius pereina iš chaotiniu virpesiu i periodiniu virpesių režimą. Periodinių virpesių dažnis šiuo atveju sutampa su išorinès jègos dažniu, t. y. stabilizuojama pirmoji nestabili periodinè orbita. Naudojant RNGR2 metodą, valdančioji jèga nevirsta nuline kaip UGR metode, bet išlieka baigtinio dydžio (apie 10\%, lyginant su osciliatoriaus išejimo signalu). RNGR2 metodas nekeičia tik pirmosios periodinių virpesių harmonikos, bet gali keisti aukštesniąsias harmonikas. Skaitiniai ir eksperimento rezultatai rodo, kad valdančios jègos sudètyje vyrauja antrosios harmonikos sandas, todèl RNGR2 valdiklį nesunku patobulinti, ijungiant papildomą antros eilès rezonatorių, suderintą antrajai harmonikai, t. y. paverčiant ji RNGR4 valdikliu. 